\title{
Building the Best: The Academy-Industry Interface Experience at The Guildhall at SMU
}

\author{
Peter E. Raad, Ph.D., P.E., FASME \\ Linda Wertheimer Hart Professor \\ Executive Director, The Guildhall at SMU \\ SMU, Dallas, Texas, USA
}

\begin{abstract}
The video game industry has expressed a serious need for credentialed professionals to support its dramatic growth. Given the young age of the emerging discipline of interactive media, early educational efforts have by and large not benefited from a systematic discourse on what constitutes a proper and credible education, and to what ends. In the interest of contributing to the discourse, this talk will (i) examine frameworks underpinning game education and its positioning within a larger academic context, (ii) present ideas that may be helpful in shaping the tenets of the new discipline, and (iii) share insights and experience gained over the last eight years in establishing The Guildhall at SMU and offering its programs.
\end{abstract}

\section{Longer Abstract}

The universal popularity of video games has transformed what began as a hobby pursuit into a worldwide booming industry that rivals the movie industry in revenues and lure. This dramatic growth coupled with significant advances in computing and graphics power, and fueled by ever increasing consumer expectations has driven the need for talent well beyond the traditional pool of selfmotivated, self-taught amateurs aspiring to be game developers. The video game industry expressed their serious and immediate needs, and a handful of universities responded with locally grown educational and training programs. As these trailblazing institutions struggled to define appropriate curricula, explain to society at large the importance of an emerging discipline, and gain acceptance within traditional academia, other institutions of higher learning, both non-profit and for-profit, sensed the popularity of games with teenagers and young adults, and moved to capitalize on the attraction with offerings varying from courses, to minors, and even to majors. Given the young age of the emerging discipline of interactive media, it is understandable that early efforts have by and large not benefited from a thoughtful and systematic discourse on what constitutes a proper and credible education, and to what ends. In the interest of contributing to the discourse, this talk will (i) examine frameworks and issues around game education and the positioning of the emerging specialization within a larger context of an academic discipline, (ii) present ideas and advance opinions that may be helpful in shaping the tenets of the new discipline, and (iii) share insights and practical experience gained over the last eight years in establishing The Guildhall at SMU and offering its programs.

\section{About The Guildhall at SMU}

The Guildhall at SMU was incubated in 2002 as a direct response to the expressed needs of the gaming industry's leaders for professionals who have been educated and trained at the intersection of the arts and sciences of digital game development. The novel curriculum that emerged melds the benefits of the academic and apprenticeship models to help produce immediate practitioners and future leaders for an emerging discipline that will undoubtedly play a key role in how human beings will express themselves and interact. The Guildhall two-year graduate-level program is an intense project-oriented educational experience that melds the theory and practice of game development, and provides opportunities for students to hone their game making abilities by working in cross-disciplinary teams. SMU offers the Master of Interactive Technology and the Professional Certificate in Digital Game Development with specializations in Art Creation, Level Design, and Software Development.

\section{About the Speaker:}

Peter E. Raad holds the Linda Wertheimer Hart Professorship and is a full professor of mechanical engineering at SMU in Dallas, TX. He is the founding Director of the Linda and Mitch Hart eCenter at SMU, and the founding Executive Director of The Guildhall at SMU, a novel, industry-university crossdisciplinary, graduate program designed to educate and train future practitioners and innovators in the fast-growing field of digital game development. Previously, he served as the Associate Dean of the SMU School of Engineering.

Prof. Raad has received several awards, including 
four times the Outstanding Graduate Faculty Award, twice the Outstanding Undergraduate Faculty Award, and the Sigma Xi Faculty Research Award. In 19992000, he was named the ASME North Texas Section Engineer of the Year, and in 2006 he received the Harvey Rosten Award for Excellence in the thermal analysis of electronic components. Also in 2006, he received the Best Paper Award at the IEEE Semiconductor Thermal Modeling, Measurement and Management Symposium. In 2007, Dr. Raad was included in Next-Gen's Top 25 most influential people in the video gaming industry for 2007.

Dr. Raad has published over 45 journal articles and over 100 conference papers. He holds US and international patents in thermal metrology and computational characterization of multi-scale integrated circuits. He has received over $\$ 2.5 \mathrm{M}$ in funding from government and industry in support of his extensive research in tsunami mitigation and solid-fluid wave interactions, as well as his founding in 1995 of an industry-university collaborative laboratory dedicated to the computational modeling and laser-based measurement of submicron electronic devices. In 2007, he founded TMX Scientific, Inc., to commercialize novel thermal metrology and analysis tools for complex microelectronic devices.

Dr. Raad is a Fellow of ASME, Senior Member of IEEE, member of the APS and the Sigma Xi research society, and a 1979 elected member of Tau Beta Pi. $\mathrm{He}$ is a Licensed Professional Engineer in the State of Texas. He received his BSME, MS, and Ph.D. in mechanical engineering from the University of Tennessee at Knoxville.

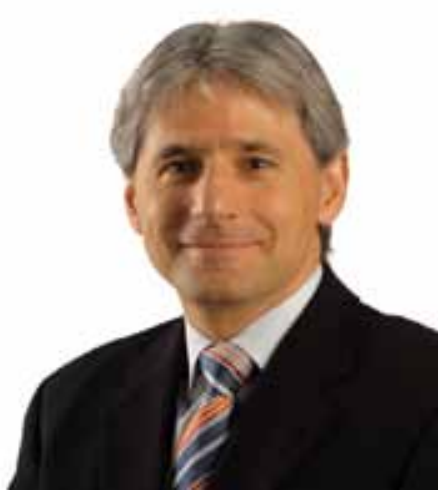

